\title{
ПСИХОЛОГІЧНІ УСТАНОВКИ, КОМПЕТЕНЦІЇ ТА ОСОБИСТІ ЯКОСТІ ВИКЛАДАЧА ЯК ФАКТОР РОЗВИТКУ МАТЕМАТИЧНОЇ ОБДАРОВАНОСТІ УЧНЯ
}

\author{
Бончук Н. В., \\ аспірант кафедри загальної психологї \\ Київський національний університет імені Тараса Шевченка
}

DOI: https://doi.org/10.31435/rsglobal_ijitss/28022020/6944

\section{ARTICLE INFO}

Received 15 December 2019 Accepted 10 February 2020 Published 28 February 2020

\section{KEYWORDS}

mathematical giftedness, teacher competencies, competence, teacher training, professional setting.

\begin{abstract}
The article deals with the problem of the role of professional competences, personal characteristics and psychological attitudes of the subject-teacher in the development of mathematical giftedness of students. The substantiation of the competence model of a teacher working with mathematically gifted children is presented. The urgency of the problem of formation of necessary competences for work with mathematically gifted students is substantiated. The three-level model of teacher's professional competence is considered as a set of key professional (reflecting the specificity of a certain professional activity, in our case - pedagogical) and special (reflecting the specificity of working in different conditions of professional activity with talented children) competencies.

Within the competency model, the components of the cognitive, behavioral, and value components are examined. The role of the psychological ettitudes of the teacher in the motivational component of the educational process is substantiated. A number of problems of professional and personal development of teachers in the organization of teaching of mathematically gifted students have been identified. Recommendations are given for the construction of a postgraduate teacher education program aimed at the discovery and psychological and pedagogical support of mathematical talent.
\end{abstract}

Citation: Bonchuk N. V. (2020) Psychological Attitudes, Competences and Personal Qualities of the Teacher as a Factor for the Development of the Mathematical Giftedness of the Student. International Journal of Innovative Technologies in Social Science. 2(23). doi: 10.31435/rsglobal_ijitss/28022020/6944

Copyright: (C) 2020 Bonchuk N. V. This is an open-access article distributed under the terms of the Creative Commons Attribution License (CC BY). The use, distribution or reproduction in other forums is permitted, provided the original author(s) or licensor are credited and that the original publication in this journal is cited, in accordance with accepted academic practice. No use, distribution or reproduction is permitted which does not comply with these terms.

Вступ. Науково-технічний прогрес та економічні зміни, що відбуваються сьогодні в Україні та загалом у всьому світі, мають безпосереднє відображення в теорії та практиці виховання й навчання. Наразі основним завданням сучасної освіти $€$ забезпечення всебічного розвитку здібностей кожної людини, сприяння максимальному розкриттю та реалізації, формуванню всебічно розвиненої, творчої особистості, здатної до повної самореалізації, активної участі в перетворенні суспільства. Важливою метою сучасної освіти в Україні є збереження і розвиток розумового і творчого потенціалу здібних дітей, вдосконалення виявлення та організації безперервного супроводу обдарованості в умовах сучасного освітнього простору. Закономірно, що інтерес багатьох дослідників з психолого-педагогічної сфери прикутий до проблеми виявлення й розвитку математично обдарованих дітей, як майбутнього ядра інтелектуальної еліти.

Задача виявлення й розвитку математичної обдарованості була і залишається до кінця невирішеною у всьому світі. Рання діагностика, відбір, наявність спеціалізованих шкіл 3 математичних ухилом, а також проведення математичних конкурсів та олімпіад не рятує ситуацію, оскільки багато обдарованих учнів з різних куточків країни все одно нерідко залишаються без 
належного психолого-педагогічного супроводу. Окрім того, хоча обдарованість - це цінний ресурс, будь-які здібності мають тенденцію до згасання, якщо вчасно не виявити їх, не розвивати, не підтримувати в учневі належну мотивацію до зростання, до безупинної роботи над собою, до адекватного переживання труднощів i невдач. Будь-який талант - це швидше результат зацікавленості й невтомної праці, ніж схильність до виконання певної діяльності. Тому задачею педагога $€$ виявити, розкрити і в будь-який спосіб примножити здібності математично обдарованого учня. А це, в свою чергу, залежить від того, якими особистісними рисами володіє такий педагог, які він має психологічні характеристики та професійні компетенції.

Постановка проблеми. У вітчизняній психолого-педагогічній практиці до цих пір не викоренене протиріччя між необхідністю розвивати здібності дитини відповідно до іiі природних нахилів та здібностей і типової шкільної програми навчання, орієнтованої на середні темп навчання та рівень здібностей. Тому частина школярів (серед яких є обдаровані) відразу академічно відстають і поповнюють ряди неуспішних учнів, інші нудьгують i втрачають навчальні азарт та інтерес від занадто повільного темпу освітньої програми.

Проблема також у тому, що далеко не всі педагоги й психологи українських шкіл мають достатню кваліфікацію для виявлення математичної обдарованості в учнях й розвитку їхнього потенціалу, через що частина дітей з високим рівнем здібностей з часом переходить у категорію «звичайних», оскільки останні втрачають всяку мотивацію до поглибленого розвитку.

Питання компетентності фахівців (педагогів, психологів, тьюторів), що працюють 3 математично обдарованими дітьми, містить ряд проблемних аспектів. Окремі 3 них: у науці відсутнє єдине розуміння генези та самого феномену обдарованості; немає чітко окреслених вимог до особистості педагога, який має розвивати обдарованого учня; фактична відсутність теоретичної та практичної підготовки вчителів до розуміння й розпізнавання обдарованості серед учнів, відсутність практики співпраці з математично обдарованими дітьми в роботі вчителя-предметника.

Аналіз актуальних досліджень. В Україні проблемі обдарованості особистості присвячені дослідження В.О. Моляко, О.І. Кульчицької, В.В. Клименка, О.Л. Музики, О.В. Бобир, О. В. Зазимко, Н. М. Куліш, М. Ю. Якимчук та ін.

Теорії математичних здібностей та обдарованості, шляхам їх розвитку присвячено праці А.М. Колмогорова, В.А. Крутецького, О.А. Крюкової, В.М. Дружиніна, Е.О. Голубєвої, I.В. Дубровіної, О.П. Гусєвої, І.А. Льовочкіної, В.М. Сапожнікова, В.В. Суворової, А.П. Капалайте, С.О. Ізюмової, С.Г. Бутоліна, Т.М. Хрустальової, О.І. Сибірякової та ін.

В науковій літературі існують різні погляди стосовно того, якими якостями має володіти викладач математики в інтелектуально обдарованих учнів. Накопичений значний арсенал сучасних науково-практичних та методичних напрацювань 3 проблеми підготовки педагога до роботи 3 обдарованими дітьми й молоддю у вищих і загальноосвітніх навчальних закладах (Г.М. Анохіна, Ю.З. Гільбух, М.М. Кашапов, .Н. Татарінова, Г.Ю. Ульянова, .В. Шавініна, М.Г. Шемуда, Л. Яковлева та ін.) Н. С. Лейтес, О.М. Матюшкін, Л.В.Попова і В.С.Юркевич обгрунтували необхідність підготовки педагога до роботи з обдарованими учнями, підтримували думку про те, що вчитель обдарованих школярів повинен володіти особливим психічним складом.

Різні аспекти підготовки як майбутніх, так і вже працюючих педагогів до роботи 3 талановитими дітьми знайшли відображення в дисертаційних дослідженнях Л. М. Андрєєвої, Л. К. Веретенникова, Т. І. Воронової, Н.В.Дудирєвої, О.Б.Мочалова, О.В.Пажитнєвої, Т. Г. Рахматулліна, Г. В. Тарасової, Г. Т. Шпарєвої та ін.

Мета статті - розглянути роль особистісних характеристик, психологічних установок та професійних компетенцій вчителя-предметника в розвитку здібностей математично обдарованого школяра.

Виклад основного матеріалу. Перед вчителем математично обдарованого школяра стоїть доволі важка задача безперервного самовдосконалення як педагога, дослідника i математика протягом всього трудового шляху, в інакшому випадку його робота стане неефективною i втратить сенс. Такий вчитель повинен мати солідну мотивацію для саморозвитку, бо його праця, зважаючи на іï специфіку, постійно міститиме нові виклики. Спочатку з'ясуємо, які компоненти математичної обдарованості має розвивати вчитель.

Дослідник математичної обдарованості $\quad$ В.А. Крутецький всебічно вивчав дітей 3 математичною обдарованістю і описав структуру математичних здібностей. До неї увійшли такі компоненти [5]: 
1. Отримання математичної інформації. Здатність до формалізованого сприйняття математичного матеріалу, схоплювання формальної структури задач

2. Переробка математичної інформації. У неї входять:

а) здатність до логічного мислення у сфері кількісних і просторових відносин, числової і знакової символіки; здатність мислити математичними символами;

б) здатність до швидкого й широкого узагальнення математичних об'єктів, відносин і дій;

в) здатність до згортання процесу математичного міркування і системи відповідних дій; здатність мислити згорнутими структурами;

г) гнучкість розумових процесів в математичній діяльності;

д) прагнення до ясності, простоти, економності та раціональності рішень;

е) здатність до швидкої і вільної перебудови спрямованості розумового процесу, переключення думки із прямого на зворотній хід.

3. Зберігання математичної інформації. Математична пам'ять - узагальнена пам'ять на математичні відносини, типові характеристики, схеми міркувань і доказів, методи вирішення задач і принципи підходу до них.

4. Загальний синтетичний компонент. Математична спрямованість розуму. Академічна обдарованість визначається успішністю навчання. Для виявлення дітей, які мають високі здібності в оволодінні основними навчальними дисциплінами (математикою, природознавством) використовують стандартні тести досягнень.

Для того, щоб реалізувати потенціал обдарованості дитини під час шкільного навчання математиці, педагоги і психологи повинні мати сформовану готовність до роботи 3 дитиною 3 високим рівнем інтелектуальних здібностей. На нашу думку, в системі освіти повинна існувати програма формування готовності педагогів та шкільних психологів до управління розвитком інтелектуально розвинених (здібних) школярів. Важливим фактором $є$ те, що самі викладачі мають бути зразком для наслідування - тобто вони повинні бути цікавими учням як особистості та фахівці, вони повинні бути самі включені в креативно-пошукове середовище, а їхній професійно-особистісний саморозвиток повинен всіляко заохочуватись й стимулюватись. Ми узагальнили окремі висновки стосовно постаті педагога інтелектуально обдарованого учня, i отримали наступне. Найперше, слід мати на увазі, що інтелектуальні здібності фахівців, що працюють з обдарованими учнями, мають бути відповідними рівню цих учнів, а в ідеалі - мати значний відрив. Обдарована дитина не навчатиметься математики в педагога, який володіє нижчим рівнем знань, ніж він сам. Вчитель має добре бачити «зону найближчого розвитку» дитини (Л.С. Виготський) та підводити до неї здібного учня.

Цікавим i важливим $є$ питання професійної готовності педагога працювати 3 математично обдарованими учнями, що визначається наявністю у нього теоретичних знань 3 психології та педагогіки обдарованості, і безпосереднього практичного досвіду. Варто мати розроблені психолого-педагогічні критерії, що дозволяють відслідковувати динаміку рівнів та результативність формування готовності педагогів до управління розвитком обдарованих учнів.

За результатами досліджень наукової літератури, основна маса науковців схиляються до думки, що компетентність - це сукупність знань, умінь, навичок (у певній сфері) та власного до них ставлення, що особистість набуває під час навчання та професійної діяльності [1; 7].

Дослідники і фахівці в галузі підготовки кадрів для навчання математично обдарованих дітей виокремили ряд положень відносно компетенцій - теоретичних i практичних знань $\mathrm{i}$ навичок, якими мають володіти педагоги обдарованих дітей. Сучасна наука пропонує такі визначення компетенцій та компетентності.

I. А. Зимня визначає компетенції як деякі внутрішні, потенційні, приховані психологічні новоутворення (знання, уявлення, програми (алгоритми) дій, системи цінностей і відносин), які потім виявляються в компетенціях людини як актуальних, діяльнісних проявах. Компетентність розглядається як результат оволодіння відповідною компетенцією - це складне і багаторівневе утворення. У їх структуру включені три компоненти: когнітивний (знання і розуміння), поведінковий (практичний і оперативне застосування знань) та ціннісний (цінності - органічна частина способу сприйняття дійсності та життя з іншими в соціальному контексті) [3].

За Є.В. Лебєдєвим, ці компоненти мають такий зміст:

- когнітивний компонент - це сукупність, система знань і умінь, на основі якої будується цілісна картина дійсності і здійснюється процес власне професійної діяльності; 
- поведінковий компонент - це система універсальних способів пізнання, відповідних алгоритмів поведінки i способів комунікації, орієнтованих на реалізовану професійну діяльність, розвиток у фахівця різноманітних способів, необхідних для самореалізації в професійній діяльності;

- ціннісний компонент - це розуміння змісту і значення реалізованої діяльності, суб'єктивне морально-естетичне, рефлексивне ставлення до освоюваних цінностей та способів їх освоєння, сміливість у відстоюванні своєї думки і своїх поглядів, незалежність в судженнях, почуття відповідальності за пропоновані рішення [6].

Ми узагальнили існуючі в науковій літературі погляди стосовно вчительських компетенцій, і 3'ясували, що фахівець математично обдарованого учня повинен володіти наступними компетенціями:

Таблиця. 1 Компетенції вчителя-предметника математично обдарованих учнів

\begin{tabular}{|c|c|c|}
\hline Когнітивний компонент & Поведінковий компонент & Ціннісний компонент \\
\hline 1 & 2 & 3 \\
\hline $\begin{array}{l}\text { - математична компетентність, } \\
\text { грунтовні теоретичні знання і } \\
\text { практичні навички фахівця- } \\
\text { математика; }\end{array}$ & $\begin{array}{l}\text { - володіння методами і } \\
\text { прийомами самовдосконалення; } \\
\text { здатність самостійно } \\
\text { здійснювати і контролювати хід } \\
\text { свого розвитку; готовність } \\
\text { об'єктивно оцінити досягнуті } \\
\text { результати; }\end{array}$ & $\begin{array}{l}\text { - наявність цінностей, які } \\
\text { рухають педагога до мети } \\
\text { всебічного розвитку обдарованих } \\
\text { підопічних; } \\
\text { - переведення цінностей в } \\
\text { професійно-особистісний } \\
\text { арсенал важливих якостей; } \\
\text { - реалізація цінностей в процесі } \\
\text { професійної діяльності; }\end{array}$ \\
\hline $\begin{array}{l}\text { - дослідницька компетенція } \\
\text { володіння методологічними } \\
\text { знаннями, основами } \\
\text { дослідницької діяльності, } \\
\text { методами психолого- } \\
\text { педагогічного дослідження, } \\
\text { вміння статистично обробляти } \\
\text { емпіричні дані, формулювати } \\
\text { висновки, представляти } \\
\text { результати дослідження; } \\
\text { ставлення до дослідницької } \\
\text { діяльності як до важливого } \\
\text { компоненту педагогічної праці } \\
\text { [8]. }\end{array}$ & $\begin{array}{l}\text { - наявність вмінь та навичок до } \\
\text { планування, та відбору } \\
\text { навчального матеріалу, вміння } \\
\text { застосовувати інноваційні } \\
\text { технології навчання; } \\
\text { організовувати навчально- } \\
\text { виховний процес для розвитку } \\
\text { інтелектуальних і творчих } \\
\text { здібностей обдарованих; вміння } \\
\text { аналізувати і проектувати } \\
\text { компоненти навчально- } \\
\text { розвивального середовища, } \\
\text { креативно керувати } \\
\text { дослідницькою роботою учнів, } \\
\text { здійснювати педагогічний } \\
\text { супровід процесів подальшої } \\
\text { соціалізації математично } \\
\text { обдарованих і їхнього } \\
\text { професійного самовизначення, } \\
\text { підготовки їх до усвідомленого } \\
\text { вибору майбутньої професії; } \\
\text { навички моделювання та } \\
\text { проектування освітнього } \\
\text { середовища для обдарованих } \\
\text { школярів; }\end{array}$ & $\begin{array}{l}\text { - компетенції, орієнтовані на } \\
\text { цінності вагомості праці } \\
\text { педагога, суспільну значущість } \\
\text { розвитку обдарованості, } \\
\text { відповідальність перед } \\
\text { державою, можливість } \\
\text { професійного самоствердження, } \\
\text { реалізація гуманістичних } \\
\text { цінностей через любов і } \\
\text { прихильність до дітей; }\end{array}$ \\
\hline $\begin{array}{l}\text { - компетенція в галузі методики } \\
\text { освіти (теорія і практика } \\
\text { викладання математичної } \\
\text { дисципліни); } \\
\text { - творча здатність до } \\
\text { модифікацій та розробки } \\
\text { навчальних планів, програм та } \\
\text { учбових завдань; } \\
\text { - вміння стимулювати когнітивні } \\
\text { здібності учнів; }\end{array}$ & $\begin{array}{l}\text { - комунікативна компетенція як } \\
\text { здатність і готовність до } \\
\text { різнопланових контактів } 3 \text { метою } \\
\text { вирішення комунікативних } \\
\text { завдань з усіма учасниками } \\
\text { навчально-виховного і } \\
\text { освітнього процесу (передача } \\
\text { інформації, ведення переговорів, } \\
\text { встановлення і підтримання } \\
\text { контактів і т. п.) }\end{array}$ & $\begin{array}{l}\text { - орієнтація на зростання; } \\
\text { прагнення до безперервного } \\
\text { саморозвитку і } \\
\text { самовдосконалення; } \\
\text { - розвинені навички рефлексії і } \\
\text { т. п.; }\end{array}$ \\
\hline
\end{tabular}


Продовження таблиці 1.

\begin{tabular}{|c|c|c|}
\hline 1 & 2 & 3 \\
\hline $\begin{array}{l}\text { - психолого-педагогічна } \\
\text { компетенція супроводу } \\
\text { освітнього процесу математично } \\
\text { обдарованих учнів, що } \\
\text { передбачає вміння розпізнавати } \\
\text { обдарованість, знання психології } \\
\text { обдарованості та методів } \\
\text { навчання обдарованих дітей; } \\
\text { труднощів і проблем розвитку } \\
\text { обдарованості, особистісних } \\
\text { особливостей обдарованих, } \\
\text { навички організації їхньої } \\
\text { індивідуальної освітньо- } \\
\text { виховної траєкторії, ефективної } \\
\text { колаборації всіх учасників } \\
\text { освітнього процесу; } \\
\text { вміння використовувати } \\
\text { висновки індивідуального } \\
\text { діагностичного обстеження } \\
\text { дитини для побудови їі } \\
\text { особистого навчального плану; }\end{array}$ & $\begin{array}{l}\text { - вміння консультувати учнів не } \\
\text { лише } з \text { питань їхнього навчання, } \\
\text { але й бути належним } \\
\text { вихователем, мотивувати дітей, } \\
\text { переорієнтовуючи їх з установки } \\
\text { на даність на установку } \\
\text { зростання (Керол Дуек). }\end{array}$ & \\
\hline $\begin{array}{l}\text { - компетенція технологічної } \\
\text { грамотності; здатність } \\
\text { знаходити, відбирати, обробляти } \\
\text { і використовувати необхідну для } \\
\text { розвитку обдарованості } \\
\text { інформацію (інформаційна } \\
\text { грамотність), } \\
\text { розвинене критичне мислення. }\end{array}$ & & \\
\hline
\end{tabular}

Особистість, характер і компетенції вчителя як центральної фігури розвитку потенціалу математично обдарованих дітей $є$ беззаперечно важливими. Не менш важливими $є$ особливості його світогляду, а також психологічні установки, якими він керується у своїй педагогічній практиці. Розробкою проблеми установки займалися багато психологів: А.Г. Асмолов, Д. Майерс, Ш.А. Надірашвілі, В.Г. Норакідзе, А.С. Прангішвілі, Н.І. Серджвеладзе, Д.Н. Узнадзе.

У сучасній психолого-педагогічній літературі установка розглядається, з одного боку, як внутрішня готовність особистості до конкретної діяльності, з іншого - як діяльність педагога по формуванню цієї готовності.

Наявність тієї чи іншої установки на розвиток впливає на те, як саме вчитель орієнтує учнів долати труднощі у навчанні. Іншими словами, мають значення установки, які транслюють викладачі математично обдарованим підопічним, від чого залежатиме, що саме їх мотивуватиме в розвитку математичних здібностей. Американська дослідниця Керол Дуек з'ясувала, як самі установки призводять до «втрат обдарованості». К. Дуек виокремила два різновиди установки на досягнення успіху в розвитку - установку на обдарованість як на природну даність та установку на розвиток. У своїй книзі «Гнучка свідомість. Новий погляд на психологію розвитку дорослих і дітей» вона пише про те, що обдаровані діти мають небезпеку виховуватись з установкою на даність - із знанням своєї обдарованості й відчуттям особливої переваги, які дають їхні здібності [2].

У випадку установки на даність, школяр в щоденній роботі над розвитком математичного мислення покладається насамперед на свою обдарованість. Внаслідок цього формується тенденція до уникнення невдач, що унеможливлює критичний погляд на рівень власних досягнень і посилення хибної мотивації бути першим, не докладаючи значних зусиль. Вчитель, який сам має установку на даність (впевненість в тому, що задатки і здібності - це визначальний фактор для розкриття потенціалу), може несвідомо транслювати ії дітям, через що вони цінуватимуть більше свої природні схильності, ніж знання, що здобуваються через працю, прагнутимуть легших перемог, а ось невдачі і труднощі стануть нищівними для самооцінки, через що може початись їх уникнення. 


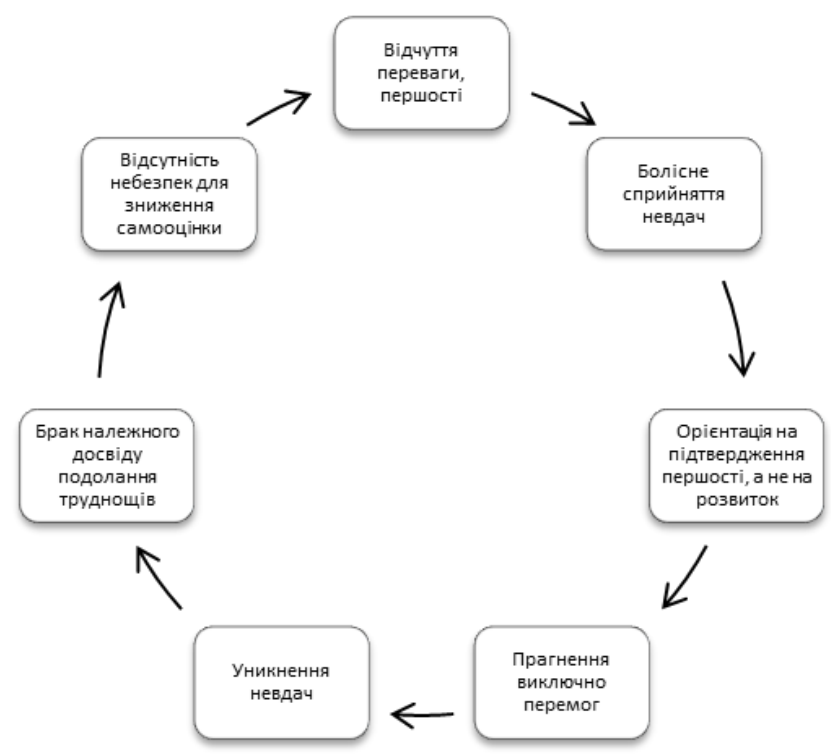

Рис. 1. Цикл установки на даність в математично обдарованих учнів.

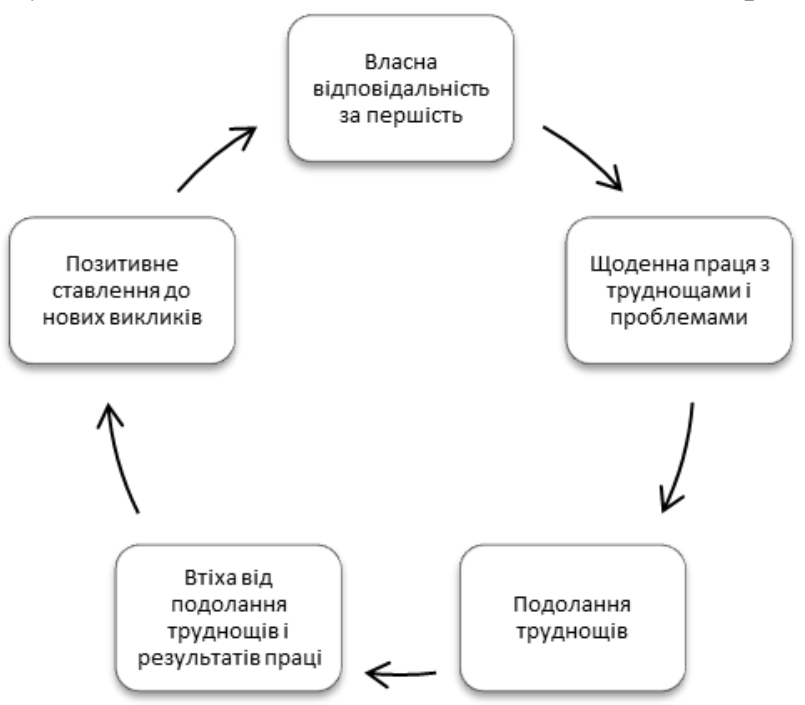

Рис. 2 Цикл установки на розвиток в математично обдарованих учнів.

Що стосується виховання орієнтації установки на зростання - то це прищеплення математично обдарованим учням думки про те, що талант згасає без щоденної важкої праці, і що обдарованість без навчальних зусиль згодом втрачається, що труднощі, невдачі та провали - це нормальна частина навчального процесу. Головне, на що слід звернути увагу - яку установку (на даність чи на розвиток) має сам викладач математичної дисципліни в обдарованих учнів. Саме його особиста установка визначатиме, які мета послання він транслюватиме школярам під час навчального процесу, і які це наслідки матиме для їхнього розвитку.

Ще один важливий момент, який стосується характеристик установок, які вчитель транслює математично обдарованим учням - це їхній гендерний аспект. За даними К. Бенбоу і Дж. Стенлі, на 13 математично обдарованих чоловіків припадає лише одна обдарована жінка. Серед учнів спеціалізованих шкіл для дітей з високим рівнем математичних здібностей більшу частину учнів становлять хлопчики. Комітет Філдсовської премії з математики вперше за 74 роки існування нагороди в 2014 році вручив ії жінці - 37-річній Мар'ям Мірзахані з Ірану. За даними ряду досліджень, в молодшій школі дівчинки складають половину математично обдарованих дітей. У старшій школі рівень оцінок дівчаток за тестами інтелекту знижується; у підсумку дівчата становлять лише одну третину обдарованих старшокласників.

Заслужений вчитель України Сергій Ліфіц, який займається навчанням математично обдарованих дітей, підготував 19 переможців міжнародних математичних олімпіад, 3 них половина дівчат. У 2017 році серед переможців були 2 українські дівчини. За його словами, 
найсерйознішою серед шкільних олімпіад з математики є Міжнародна олімпіада (IMO). Щорічно в ній беруть участь школярі більш ніж сотні країн, в кожній команді по 6 осіб. Зазвичай з цих 600 осіб дівчата становлять не більше $10 \%$. Серед психологічних причин кількісного гендерного перекосу серед обдарованих математиків, одними 3 найважливіших, на думку дослідників обдарованості, $є$ соціопсихологічні фактори. Для того, щоб давати можливість математично обдарованим дітям розкривати свій потенціал, гендерна установка вчителя має бути нейтральною.

У 1968 році американськими дослідниками Р. Розенталем та Л. Якобсоном було проведено цікавий шкільний експеримент. Вони провели тестування розумових здібностей учнів і вказали педагогам на декількох учнів, що відрізнялися підвищеними інтелектуальними здібностями. Під час експерименту дослідники навмисно ввели в оману вчителів: ними були названі випадково вибрані діти, які не мали ознак обдарованості. Проведене через рік повторне тестування дозволило зафіксувати реальне поліпшення показників розумового розвитку обраних школярів.

Отже, вчитель $є$ визначальним фактором в системі навчання обдарованих дітей. Саме тому до фахівців, які працюють з інтелектуально обдарованими, пред'являються підвищені вимоги.

Позитивна Я-концепція також становить одну з найважливіших характеристик вчителя, що працює 3 математично обдарованими дітьми. Педагог, який має занизьку самооцінку, як правило, відчуває побоювання, перебуваючи в середовищі своїх обдарованих учнів, і тому не може викликати у них поваги.

На основі аналізу наукових джерел, можемо зробити висновок, що найбільш згадуваними для вчителя обдарованих дітей специфічні якості, в науковій літературі $є$ наступні, де вчитель має:

1) бути доброзичливим і чуйним;

2) мати знання в психології розвитку обдарованих дітей, відчувати їхні потреби та інтереси;

3) мати досвід роботи в установах для дітей молодшого та дошкільного віку;

4) мати широке коло інтересів і вмінь;

5) бажано мати спеціальну освіту, окрім педагогічної (для викладача-математика обдарованих дітей педагогічна освіта може виступати другою, додатковою, тоді як перша - це спеціальна освіта саме в галузі прикладної математики);

6) бути готовим до виконання різноманітних завдань, пов'язаних 3 навчанням i вихованням обдарованих дітей;

7) бути комунікабельним, мати живий і активний характер;

8) вміти цікаво оповідати матеріал, бажано мати почуття гумору;

9) виявляти гнучкість, бути готовим до перегляду власних усталених поглядів i постійного самовдосконалення;

10) проявляти креативність, відкритість до нового, непізнаного, нетрадиційного;

11) володіти хорошим здоров'ям і життєстійкістю;

13) мати спеціальну післядипломну підготовку по роботі з обдарованими дітьми і бути готовим до подальшого отримання спеціальних знань (Enrlich, 1978).

На думку О.М. Матюшкіна, О.І. Савенкова, О.Л. Яковлєвої та ін., педагог для обдарованих дітей повинен мати психологічну готовність до розробки гнучких, освітніх індивідуалізованих програм; мати відчуття відповідальності за створення теплої, емоційно безпечної атмосфери в класі; повинен віти організувати надання школярам вчасного й інформативного зворотного зв'язку. Також він повинен бути готовим до застосування різноманітних, нетрадиційних, орієнтованих суто на індивідуальний підхід, освітніх стратегій. До того ж, такий педагог мусить поважати цінності та індивідуальність кожного учня класу, незалежно від рівня розвитку його здібностей.

На думку дослідниці А.К. Маркової, підготовка педагога, який працює із обдарованими дітьми, повинна мати міцний теоретичний і практичний фундамент, в основі якого:

1) наявність професійно-особистісної позиції у педагогів;

2) комплексний характер освіти таких педагогів;

3) створення системи психолого-педагогічного консультування й тренінгів для формування навичок самопізнання, самоконтролю, саморозвитку;

4) створення спеціальних робочих умов, що враховують вивчення передового психолого-педагогічного досвіду в роботі з обдарованими, багатоаспектний обмін досвідом 3 метою розвитку професійної майстерності; 
5) створення творчої, креативної та вільної освітньо-розвивальної атмосфери навчання на різних ступенях та у різних сферах діяльності фахівців (вчителі початкової школи, вчителіпредметники, педагоги-дефектологи, шкільні психологи, а також представники шкільної адміністрації і т. д.) [4].

На нашу думку, основним елементом спеціальної підготовки педагога є його стажування в класі, де навчаються математично обдаровані діти. Бажано, щоб дитячий колектив при цьому був змішаним - де навчаються діти з різним рівнем математичної підготовки. Це дасть можливість педагогу відпрацювати навички індивідуального підходу до розвитку здібних дітей.

Вчителі без відповідної підготовки часто просто не можуть виявити обдарованих дітей, не знають їх психологічних особливостей; через що виявляються абсолютно не готовими до якісної роботи 3 ними. Трапляється, що такі педагоги байдужі до проблем «неформатних» учнів (вони у повній мірі не можуть їх зрозуміти); інколи навіть вороже налаштовані стосовно обдарованих дітей, які створюють певну загрозу вчительського авторитету; часом такі вчителі часто використовують для обдарованих дітей тактику кількісного збільшення завдань, а не якісну їх зміну [9]. Незважаючи на велику затребуваність кваліфікованих вчителів, здатних проводити ефективну роботу з виявлення та розвитку обдарованих дітей, рівень їх професійних компетенцій в області роботи з обдарованими дітьми поки що не задовільний. Підтвердженням цього є результати різноманітних досліджень, які показують, що у педагогів існують проблеми при роботі з такою категорією дітей. Це пов'язано, як вважають автори, 3 відсутністю необхідних знань про обдарованих дітей та несформованістю важливих якостей особистості і професійних навичок для роботи з ними.

Питання післядипломної освіти персоналу, що виховує і розвиває математично обдарованих дітей, в Україні стоїть особливо гостро. Особливо це стосується середовища загальноосвітньої школи, де обдаровані можуть вчитись пліч-опліч 3 дітьми різного рівня здібностей, в чому теж $\epsilon$ проблема, бо освітня програма налаштована на «середнього учня». Психолого-педагогічними умовами для професійного зростання таких фахівців, на нашу думку, мають бути:

1. Включення у програму підготовки вчителів (у вузах, закладах післядипломної освіти, інститутах вдосконалення вчителів) навчального модулю 3 психології обдарованості, вагома частина якого була б присвячена методам ідентифікації учнів з високим рівнем інтелектуальних здібностей, математичного інтелекту, та особливостям роботи з ними. Зазначений курс має давати знання про особистісні особливості обдарованих дітей, методи їх виховання, розвитку дослідницьких здібностей, специфіку емоційно-вольової, мотиваційної та когнітивної сфер. Окремим завданням такого курсу є формування навичок практичної розробки рекомендацій для батьків та інших педагогів щодо складання програми розвитку обдарованого учня.

2. Організація курсів підвищення кваліфікації, присвячених психолого-педагогічним проблемам роботи з обдарованими дітьми для педагогів загальноосвітніх шкіл.

3. Організація та проведення освітніх майстер-класів, семінарів, тренінгів 3 психології та педагогіки обдарованості для вчителів різних типів освітніх установ, 3 метою підвищення їх компетентності в роботі з обдарованими дітьми.

4. Можливість отримання професійного досвіду роботи з математичною обдарованістю на експериментальних майданчиках, де педагог матиме змогу на практиці оволодіти навичками первинної діагностики високих здібностей учня, проведення нестандартних занять, отримає можливість поспостерігати за поведінкою та навчальною активністю обдарованих, поспілкуватись з ними.

Висновки Успішний розвиток учнів 3 високим рівнем математичних здібностей у загальноосвітній школі вимагає професійної готовності педагогів здійснювати підтримку і розвиток дитячої обдарованості. Фігура вчителя як одного з ключових учасників розвитку математично обдарованого учня має визначний вплив на перебіг його навчальної діяльності. Особистісні характеристики вчителя-предметника $\epsilon$ важливою змінною успішності розвитку здібностей обдарованого учня. Готовність педагога математично обдарованого учня передбачає високий рівень професійної компетентності, особистісної зрілості та адекватних психологічних установок, націлених на підвищення ефективності навчально-розвивального процесу. Сформованість професійних компетенцій вчителів для роботи 3 математично обдарованими дітьми $є$ одним із визначальних факторів успішного їх розвитку. Володіння трирівневою моделлю компетенцій неможлива без спеціальної підготовки, яка на сьогоднішній день має ряд проблем, пов'язаних 3 відсутністю затверджених підходів і технологій до організації даного процесу. 
Для поглиблення таких компетенцій необхідно озброїти шкільні адміністрації та персонал знаннями про психолого-педагогічні засади діяльності з виявлення, навчання i розвитку учнів з явною, неявною, потенційною та парціальною математичною обдарованістю через створення та впровадження спецкурсів і програм навчання та стажування педагогів.

\section{ЛIТЕРАТУРА}

1. Головань М. С. Компетенція та компетентність: порівняльний аналіз понять / М. С. Головань // Педагогічні науки: теорія, історія, інноваційні технології. - 2011. - № 8. - С. 224-233.

2. Дуэк К. Гибкое сознание: новый взгляд на психологию развития взрослых и детей / Кэрол Дуэк. М.: Манн, Иванов и Фербер, 2013. - 400 с.

3. Зимняя И. А. Ключевые компетентности как результативно-целевая основа компетентностного подхода в образовании [Текст] / И. А. Зимняя. - М.: Исследовательский центр проблем качества подготовки специалистов, 2004. - 40 с.

4. Ильницкая И.Л. Подготовка педагогов к выявлению и развитию одаренности детей и подростков // Опыт работы с одаренными детьми в современной России: сб. материалов Всерос. науч.-практ. конф. - М., 2010. - С. 188-192.

5. Крутецкий, В.А. Психология математических способностей школьников / под ред. Н.И. Чуприковой. - М.: Изд-во МПСИ; Воронеж: МОДЭК, 1998. - 416 с.

6. Лебедев, Е.В. Формирование исследовательской компетентности у будущих менеджеров в процессе их подготовки к профессиональной деятельности в вузе [Текст]: дис. ... канд. пед. наук / Е В. Лебедев. - Ярославль, 2009. - 185 с.].

7. Лейко С. В. Поняття «компетенція» та «компетентність»: теоретичний аналіз / С. В. Лейко // Педагогіка. - 2013. -№ 8. - С. 128-135

8. Подготовка научных кадров и формирование научно-исследовательских компетенций [Текст]: монография / под науч. ред. М. Н. Новикова. - Ярославль: Изд-во ЯГПУ, 2009. - 211 с.

9. Психология одаренности детей и подростков / под ред. Н. С. Лейтеса. М., 1996. С. 203-214. 